\title{
ANALYSIS OF FACTOR AFFECTING THE INTEREST OF USING ELECTRONIC MONEY WITH TAM METHOD
}

\author{
Martua Hami Siregar \\ Computer Technology \\ Universitas Bina Sarana Informatika \\ www.bsi.ac.id \\ martua.mhe@bsi.ac.id
}

\begin{abstract}
The development of electronic money is currently growing very rapidly. This is marked by the rise of merchants who provide promos and ease of use of electronic money. To find out the perception of public interest in the use of electronic money, further research is needed using the Technology Acceptance Model (TAM) Method. TAM is a technology acceptance model that can be used to determine a person's perceptions of attitudes and behavior when using certain technologies. The results showed that the use of electronic money can be accepted by the public as a legal means of payment. There is a positive and significant effect of Perceived Usefulness on Attitude Towards Using, There is a positive and significant influence of Perceived Usefulness on Intention to Use, There is a positive and significant influence on Attitude Towards Using on Intention to Use and There is a positive and significant influence on Intention to Use on Actual Usage.
\end{abstract}

Keywords: Electronic Money, Payment Instruments, Technology Acceptance Model.

\begin{abstract}
Abstrak
Perkembangan uang elektronik saat ini tumbuh sangat pesat. Hal ini ditandai dengan maraknya merchant yang menyediakan promo dan kemudahan dalam penggunaan uang elektronik. Untuk mengetahui persepsi minat masyarakat terhadap penggunaan uang elektronik perlu dilakukan penelitian lebih jauh dengan menggunakan Metode Technology Acceptance Model (TAM). TAM adalah sebuah model penerimaan teknologi yang dapat digunakan untuk mengetahui persepsi sikap dan perilaku seseorang ketika menggunakan teknologi tertentu. Hasil penelitian menunjukkan bahwa penggunaan uang elektronik dapat diterima oleh masyarakat sebagai alat pembayaran yang sah. terdapat pengaruh positif dan signifikan Perceived Usefulness terhadap Attitude Towards Using, Terdapat pengaruh positif dan signifikan Perceived Usefulness terhadap Intention to Use, Terdapat pengaruh positif dan signifikan Attitude Towards Using terhadap Intention to Use dan Terdapat pengaruh positif dan signifikan Intention to Use terhadap Actual Usage.
\end{abstract}

Kata kunci: Uang Elektronik, Alat Pembayaran, Model Penerimaan Teknologi.

\section{INTRODUCTION}

The development of information technology has had a major impact on the banking industry. Currently, the government and banks are actively promoting the use of electronic money campaigns. Various electronic money innovations have emerged as part of the trends and lifestyles of urban communities.

The development of electronic money will have an impact on the competition for providers of electronic money products which is increasingly competitive by delivering features that can replace payment cash (Salsabila \& Giri, 2017).
Today in Indonesia, the development of electronic money (or what is called unique) as an alternative to non-cash payment is not only in the form of cards but also in other forms stored on smartphones. The issuers are developing, not only banks but also non-bank institutions (LSB), such as financial companies, telecommunications companies, or public transportation companies. Several electronic money products are issued by banks, including the Flazz card from Bank BCA, emoney card from Bank Mandiri, Brizzi card from Bank BRI, TapCash card from Bank BNI, Jak Card from Bank DKI Jakarta, Mega Cash from Bank 
Mega, Nobu E-Money from National Nobu Bank. (Usman, 2017).

The results of this study prove that the perception of benefits has a positive effect on interest in using electronic money. This means that it is getting bigger perceived benefits will increase interest in using electronic money (Pratama \& Suputra, 2019).

To find out the perception of public interest in the use of electronic money, further research is needed using the Technology Acceptance Model (TAM) Method. TAM is a technology acceptance model that can be used to determine a person's perceptions of attitudes and behavior when using certain technologies. (Halim \& Darma, 2019)

The price suitability variable is a variable that has a positive effect and the biggest significant to the variable using interest (Candraditya, 2013).

TAM is an information systems theory that models how users are willing to accept and use technology. This model proposes that when users are offered to use a new system, several factors influence their decisions about how and when to use the system, especially in terms of usefulness (users believe that using this system will improve their performance), ease of use ( where the user believes that using this system will free him from difficulties, in the sense that the system is easy to use) (Utami, 2017).

Simultaneously, perceived usefulness and perceived ease of use have a significant effect on the interest in using the SAKUKU electronic money service. The relationship between perceived usefulness and interest is very strong. (Irianto, 2020). Perceived benefits partially have a significant effect on interest in using the SAKUKU electronic money service. The relationship between perceived ease of use and interest is very strong. The perceived ease of use partially has a significant effect on the interest in using the SAKUKU electronic money service (Kevin Anarjia, 2018).

Based on the table above, it shows that there is a significant influence between the use of debit cards and the use of electronic money (emoney) together on student consumption expenditures (F-count $=49.776>\mathrm{F}$ table $=3.072, \mathrm{p}$ $=0.000<\alpha=0.050)$. This shows that the simultaneous change in the use of debit cards and the use of electronic money (e-money) will significantly change student consumption expenditures (Ramadani, 2016).

Based on simultaneous testing ( $F$ test), perceived ease of use (X1), perceived usefulness (X2), and perceived risk (X3) have a significant effect on intention to use (Y) money Mandiri. Perceived ease of use (X1), perceived usefulness (X2), and perceived risk (X3) have a 32\% effect on the intention to use (Y) of Mandiri e-money. Based on the partial test results ( $t$-test), perceived ease of use (X1) has a significant effect on the intention to use (Y) of Mandiri e-money. Based on the partial test results ( $t$-test), perceived usefulness (X2) has a significant effect on the intention to use (Y) of Mandiri e-money. Based on the partial test results (t-test), perceived risk (X3) has a significant effect on the intention to use (Y) of Mandiri e-money (Alza \& Rikumahu, 2019).

Electronic money services have provided benefits and ease of use, as can be seen from the categorization of respondents' perceptions of the people of Semarang who consider electronic money services to provide benefits and convenience in high categorization assessments. Likewise with the categorization of risk perceptions according to respondents from the city of Semarang who gave low scores to risk perceptions. This means that electronic money services have provided convenience and provided various high benefits so that users will be more interested and willing to use electronic money services. Moreover, electronic money services have a low risk, this can be one of the considerations for someone to use electronic money services or not to use them (Priambodo \& Prabawani, 2016).

Attitudes, perceived benefits, perceived ease of use, subjective norms, and perceptions of behavioral control influence interest in using emoney, while perceptions of performance risk, social risk, time risk, financial risk, and security risk do not show any influence on interest in using e-money. (Rahmatika \& Fajar, 2019).

The perceived benefit variable has a significant effect on the interest in using e-money card products with a $t$ value of 9,842 and $a$ significance of 0.000 (less than 0.05) (Wibowo et al., 2015).

Factors consisting of benefits (X1), trust (X2), self-efficacy (X3), ease of use (X4), and security (X5) have a significant influence on consumer perceptions (Y) 58.3\%. This result reflects that these five factors are considered important because become the reason consumers use e-money in Indonesia (Pratiwi \& Dewi, 2018).

The better a person's perceived usefulness users of the Mandiri E-Money electronic money card will also be increasingly interested in using it increased (Kusuma, Nuruni Ika . Izaak, Wilma C . Hardiyani, 2020).

From previous research, it is known that electronic money can be accepted as a legal 
transaction tool and can be accepted by the public. However, it is necessary to know what are the reasons or factors that influence the real use of electronic money as a legal transaction tool and how the real use of e-commerce electronic money affects public transaction activities.

\section{RESEARCH METHOD}

\section{Research Design}

The research steps must be carried out in stages so that the research can give results by the hypothesis. The following are the stages of the research design, namely:

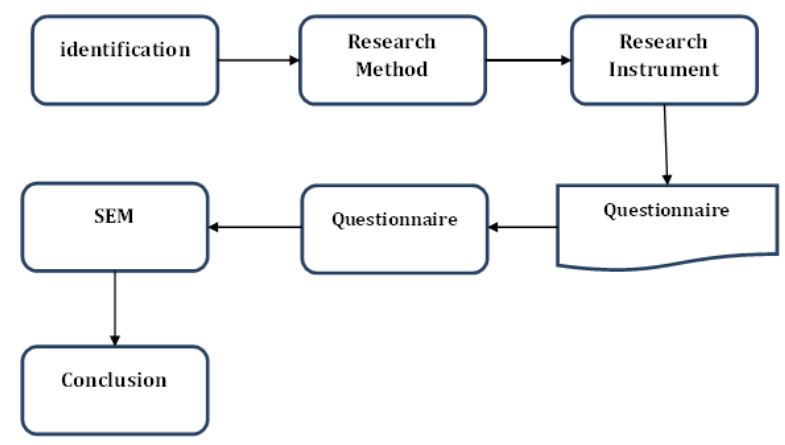

Figure 1. Research Design

The first stage in the research is to identify the problem. Identification is carried out to formulate problems and analyze these problems. Then determine the research method taken using SEM. After that, design the research instrument and then create a questionnaire. After the questionnaire is complete, then distribute it to respondents. The results of the questionnaire were processed using the SEM method. Then get the results and conclude the study.

\section{Data Source}

The research data comes from respondents who actively use electronic money as a means of payment.

\section{Stages of TAM Method}

TAM consists of two main constructs, namely perceived use of use and perceived usefulness, which determine a person's intense behavioral intention to use technology. The actor's intensity is how much a person wants to take a certain action. Perceived usefulness and perceived ease of use influence behavioral intention, but not the other way around. The use of technology will have a behavioral intention to use technology (actor's interest) if the system or technology is useful and easy to use. If the system is very useful, easy to use, or not will still be used. The following is the TAM model, namely:

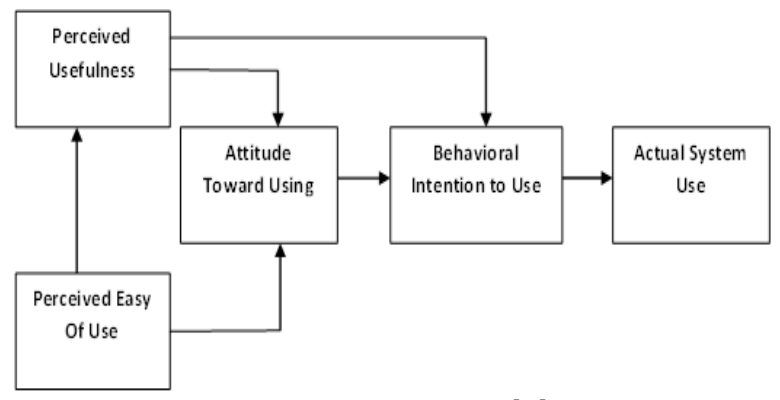

Figure 2. TAM Model

\section{RESULT AND DISCUSSION}

The specifications of the measurement model used are latent variables: CSE (Computer Self Efficacy), PU (Perceived Usefulness), PEOU (Perceived Easy of Use), ATU (Attitude Towards Using), IU (Intention to Use), and AU (Actual). Usage). The Structural Model specification uses structural equations that state a causal relationship between various constructs by forming a measurement model for exogenous and endogenous latent variables.

1. PEOU is influenced by CSE

2. PU is influenced by PEOU and CSE

3. ATU is influenced by PU and PEOU

4. IU is influenced by ATU and PU

5. AU is affected by IU

The following are the results of the CSE variable research (Computer Self Efficacy)

Table 1 Construct Reliability Computer Self Efficacy

\begin{tabular}{ccc}
\hline Variable & $\begin{array}{c}\text { Standardized } \\
\text { Loading }\end{array}$ & $\begin{array}{c}\text { Measurement } \\
\text { Error }\end{array}$ \\
\hline CSE_1 & 0,66 & 0,56 \\
CSE_2 & 0,74 & 0,46 \\
CSE_3 & 0,71 & 0,50 \\
\hline Total & 2,11 & 1,52 \\
\hline
\end{tabular}

Construct Realiability $\frac{\left(\sum \text { std loading }\right)^{2}}{\left.\left(\sum \text { std loading }\right)^{2}+\sum \varepsilon \hat{)}\right)} \ldots$

Construct Realiability $=\frac{(2,11)^{2}}{(2,11)^{2}+1,52}$

Construct Realiability $=0,75$

Table 1 calculations, shows that the value of Construct Reliability for the latent variable Computer Self Efficacy $=0.75$. This indicates that 
the indicators in each construct are consistent in measuring the construct. The results of the research variable PU (Perceived Usefulness) can be seen in table 2 .

Table 2 Construct Reliability PU (Perceived Usefulness

\begin{tabular}{ccc}
\hline Variable & $\begin{array}{c}\text { Standardized } \\
\text { Loading }\end{array}$ & $\begin{array}{c}\text { Measurement } \\
\text { Error }\end{array}$ \\
\hline PU_1 & 0,43 & 0,82 \\
PU_2 & 0,71 & 0,50 \\
PU_3 & 0,77 & 0,40 \\
PU_4 & 0,77 & 0,41 \\
Total & 2,68 & 2,13 \\
\hline
\end{tabular}

Construct Realiability $\frac{\left(\sum \text { std loading }\right)^{2}}{\left.\left(\sum \text { std loading }\right)^{2}+\sum \varepsilon \hat{\jmath}\right)}$.......

Construct Realiability $=\frac{(2,11)^{2}}{(2,11)^{2}+1,52}$

Construct Realiability $=0,75$

From the result of the calculation of table 1 above, it can be seen that the value of construct reliability for the latent variable computer self eficacy $=0,75$. This shows that the indicators in each construct are consistent in measuring the construct. Results of research on the PEOU variable (Perceived Easy of Use) variables are shown in table 3.

Table 3 Construct Reliability PEOU (Perceived Easy

\begin{tabular}{ccc}
\multicolumn{3}{c}{ of Use) } \\
Variable & $\begin{array}{c}\text { Standardized } \\
\text { Loading }\end{array}$ & $\begin{array}{c}\text { Measurement } \\
\text { Error }\end{array}$ \\
\hline PEOU_1 & 0,75 & 0,44 \\
PEOU_2 & 0,86 & 0,26 \\
PEOU_3 & 0,44 & 0,80 \\
PEOU_4 & 0,36 & 0,87 \\
\hline Total & 2,41 & 2,37 \\
\hline
\end{tabular}

Construct Realiability $\frac{\left(\sum \text { std loading }\right)^{2}}{\left.\left(\sum \text { std loading }\right)^{2}+\sum \varepsilon \hat{~}\right)} \ldots$

Construct Realiability $=\frac{(2,41)^{2}}{(2,41)^{2}+2,41}$

Construct Realiability $=0,71$

From table 3 calculations, it shows that the value of Construct Reliability for the latent variable Perceived Easy of Use $=0.71$. This indicates that the indicators in each construct are consistent in measuring the construct.

The results of research on ATU variables (Attitude Towards Using) can be seen in table 4 .

Table 4 Construct Reliability ATU (Attitude Towards Using)

\begin{tabular}{ccc}
\hline Variable & $\begin{array}{c}\text { Standardized } \\
\text { Loading }\end{array}$ & $\begin{array}{c}\text { Measurement } \\
\text { Error }\end{array}$ \\
\hline ATU_1 & 0,69 & 0,53 \\
ATU_2 & 0,56 & 0,69 \\
ATU_3 & 0,40 & 0,84 \\
ATU_4 & 0,39 & 0,85 \\
\hline Total & 2,04 & 2,91 \\
\hline
\end{tabular}

Construct Realiability $\frac{\left(\sum \text { std loading }\right)^{2}}{\left.\left(\sum \text { std loading }\right)^{2}+\sum \varepsilon \hat{)}\right)} \ldots$

Construct Realiability $=\frac{(2,04)^{2}}{(2,04)^{2}+2,91}$

Construct Realiability $=0,59$

Table 4 calculation shows that the value of Construct Reliability for the latent variable Attitude Toward Using $=0.59$. This indicates that the indicators in each construct are consistent enough to measure the construct. The results of research on the IU variable (Intention to Use) can be seen in table 5 .

Table 5 Construct Reliability IU (Intention to Use)

\begin{tabular}{ccc}
\hline Variable & $\begin{array}{c}\text { Standardized } \\
\text { Loading }\end{array}$ & $\begin{array}{c}\text { Measurement } \\
\text { Error }\end{array}$ \\
\hline IU_1 & 0,59 & 0,66 \\
IU_2 & 0,68 & 0,54 \\
IU_3 & 0,41 & 0,83 \\
IU_4 & 0,62 & 0,62 \\
IU_5 & 0,56 & 0,68 \\
IU_6 & 0,64 & 0,56 \\
\hline Total & 3,50 & 3,89 \\
\hline
\end{tabular}

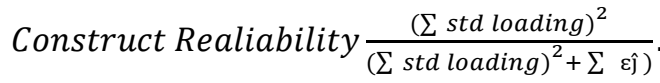

Construct Realiability $=\frac{(3,50)^{2}}{(3,50)^{2}+3,89}$

Construct Realiability $=0,76$

From table 5 calculations, it shows that the value of Construct Reliability for the latent variable Intention to Use $=0.76$. This indicates that the indicators in each construct are consistent in measuring the construct. The results of research on 
the AU (Actual Usage) variable can be seen in table 6.

Table 6 Construct Reliability AU (Actual Usage)

\begin{tabular}{ccc}
\hline Variable & $\begin{array}{c}\text { Standardized } \\
\text { Loading }\end{array}$ & $\begin{array}{c}\text { Measurement } \\
\text { Error }\end{array}$ \\
\hline AU_1 & 0,57 & 0,68 \\
AU_2 & 1,00 & 0,00 \\
\hline Total & 1,57 & 0,68 \\
\hline
\end{tabular}

Construct Realiability $\frac{\left(\sum \text { std loading }\right)^{2}}{\left.\left(\sum \text { std loading }\right)^{2}+\sum \varepsilon \hat{)}\right)} \ldots$

Construct Realiability $=\frac{(1,57)^{2}}{(1,57)^{2}+0,68}$

Construct Realiability $=0,78$

From the calculations above, it shows that the value of Construct Reliability for the latent variable Actual Usage $=0.78$. This indicates that the indicators in each construct are consistent in measuring the construct.

Following are the results of the final TAM model, namely:

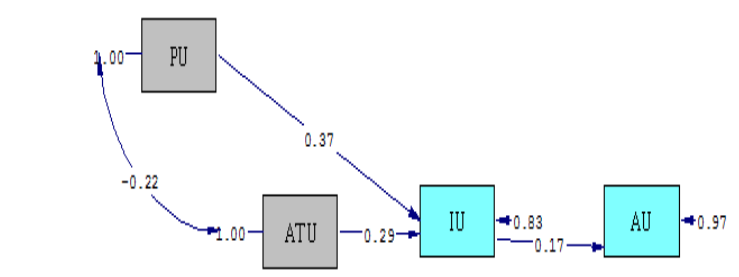

Chi-Square $=9.70, d f=2, P-$ value $=0.00784$, RUSEA $=0.146$

Figure 3. Result Research

The result is that there is a positive and significant effect of Perceived Usefulness on Attitude Towards Using, There is a positive and significant effect of Perceived Usefulness on Intention to Use, There is a positive and significant influence on Attitude Towards Using on Intention to Use and There is a positive and significant influence on Intention to Use on Actual Usage.

\section{CONLUSIONS AND SUGGESTIONS}

\section{Conclusion}

The use of electronic money can be accepted by the public as a legal means of payment. There is a positive and significant effect of Perceived Usefulness on Attitude Towards Using, There is a positive and significant influence of Perceived Usefulness on Intention to Use, There is a positive and significant influence on Attitude Towards Using on Intention to Use and There is a positive and significant influence on Intention to Use on Actual Usage. There is no positive and significant effect of Perceived Usefulness on Intention to Use. There is no positive and significant effect of Attitude Towards Using on Intention to Use. There is no positive and significant effect of Intention to Use on Actual Usage. It is necessary to study further regarding Perceived Usefulness research on Intention to Use, Attitude Towards Using on Intention to Use and Intention to Use on Actual Usage. required several variables and a more research sample. Based on research conducted on responses, respondents stated that the factors that influence the acceptance of electronic money technology are Perceived Usefulness for Attitude Towards Using, Perceived Usefulness for Intention to Use, Perceptions of Attitude Towards Using on Intention to Use and Intention to Use for Actual Usage against electronic money.

\section{Suggestion}

Research can also be used by adding other research constructs and with a varied number of respondents and specific types of electronic money.

\section{REFERENCE}

Alza, H. F., \& Rikumahu, B. (2019). Analisis Faktor Risiko Sebagai Tambahan Dalam Model Tam Dalam Penggunaan Electronic Money (Studi Kasus: E-Money Mandiri Di Kota Jakarta). Journal of Chemical Information and Modeling, 3(2), 243-255.

Candraditya, H. (2013). Analisis penggunaan uang elektronik. Diponegoro Journal of Management, 2, 1-11.

Halim, T., \& Darma, G. S. (2019). Faktor Penentu Kesuksesan Web-Based Appointment System di Rumah Sakit Taufan Halim (1) Gede Sri Darma (2). 16(4), 1-19.

Irianto, B. S. (2020). Mediasi Sikap Pada Pengaruh Kemudahan Terhadap Minat Penggunaan Informasi Akuntansi Pada Ukm Di Purwokerto. Jurnal Ekonomi, Bisnis Dan Akuntansi, 22(1), 1-13.

Kevin Anarjia, J. Z. R. (2018). Pengaruh Persepsi Manfaat Dan Persepsi Kemudahan Penggunaan Terhadap Minat Menggunakan Layanan Uang Elektronik Sakuku Pt. Bank Central Asia, Tbk Kcu Cikarang. Jurnal SISTEM INFORMASI, 1(2), 1-7. 
Kusuma, Nuruni Ika . Izaak, Wilma C . Hardiyani, L. (2020). Analisis Tingkat Persepsi Konsumen Pada Minat Penggunaan Kartu E-money. Kusuma, Nuruni Ika . Izaak, Wilma C . Hardiyani, Lifia, 8(2), 147-155.

Pratama, A. B., \& Suputra, I. D. G. D. (2019). Pengaruh Persepsi Manfaat, Persepsi Kemudahan Penggunaan, dan Tingkat Kepercayaan Pada Minat Menggunakan Uang Elektronik. E-Jurnal Akuntansi, 27, 927. https://doi.org/10.24843/eja.2019.v27.i02.p 04

Pratiwi, D. F., \& Dewi, C. K. (2018). Factors (Benefits, Trust, Self-Efficacy, Ease of Use, Security) Affecting Consumer's Perception on E-Money in Indonesia. Journal of Secretary and Business Administration, 2(2), 24. https://doi.org/10.31104/jsab.v2i2.60

Priambodo, S., \& Prabawani, B. (2016). DAN PERSEPSI RISIKO TERHADAP MINAT MENGGUNAKAN LAYANAN UANG ELEKTRONIK ( Studi Kasus pada Masyarakat di Kota Semarang ) Pendahuluan Kajian Teori Perilaku Konsumen. Jurnal Ilmu Administrasi Bisnis, 5(2), 1-9.

Rahmatika, U., \& Fajar, M. A. (2019). Faktor Faktor Yang Mempengaruhi Minat Penggunaan Electronic Money: Integrasi Model Tam - Tpb Dengan Perceived Risk. Nominal: Barometer Riset Akuntansi Dan Manajemen, $\quad 8(2), \quad$ 274-284. https://doi.org/10.21831/nominal.v8i2.265 57
Ramadani, L. (2016). Pengaruh Penggunaan Kartu Debit dan Uang Elektronik (E-Money) Terhadap Pengeluaran Konsumsi Mahasiswa. Jurnal Ekonomi Dan Ekonomi Studi Pembangunan, $\quad 8(1), \quad 1-8$. https://doi.org/10.17977/um002v8i12016p 001

Salsabila, N., \& Giri, R. R. (2017). Peta Positioning Uang Elektronik Berdasarkan Persepsi Masyarakat Di Indonesia Tahun 2017. Jurnal Riset Bisnis Dan Manajemen, 10(2), 34. https://doi.org/10.23969/jrbm.v10i2.468

Usman, R. (2017). Karakteristik Uang Elektronik Dalam Sistem Pembayaran. Yuridika, 32(1), 134-166. https://doi.org/10.20473/ydk.v32i1.4431

Utami, A. D. (2017). PENGARUH KEPERCAYAAN, KEMUDAHAN, MANFAAT DAN RESIKO TERHADAP MINAT PEMBELI UNTUK MENGGUNAKAN SISTEM E-COMMERCE. Journal of Chemical Information and Modeling, 53(9), 1689-1699. https://doi.org/10.1017/CB0978110741532 4.004

Wibowo, S. F., Rosmauli, D., \& Suhud, U. (2015). Pengaruh Persepsi Manfaat, Persepsi Kemudahan, Fitur Layanan, Dan Kepercayaan Terhadap Minat Menggunakan E-Money Card (Studi Pada Pengguna Jasa Commuterline Di Jakarta). JRMSI - Jurnal Riset Manajemen Sains $\quad$ Indonesia, 440. https://doi.org/10.21009/jrmsi.006.1.06 